\title{
Od dziejów komputacji do reprezentacji wiedzy
}

\begin{abstract}
From the history of computation to knowledge representation

There are various tools that make computational problems easier to solve. Through thousands of years mankind built and refined them in order to grasp intricate operations that can help unravel the complexity of the world. History of those tools is connected with the ability to visualize, categorize and also to assign hierarchy to things and to define relations between them. Some of them have philosophical roots, other could be employed only when suitable and sufficient mathematical apparatus became available. This paper shows a path, beginning with simple tools that aided simple mathematical operations through the ones that allowed visualization of relations between things, and finally, to the combination of these two kinds, which resulted gave us the beginning of modern ontologies in the context of informatics.
\end{abstract}

Key words: ontology, computationality, knowledge representation, graph theory, history of philosophy of information

Zjawisko komputacji, czyli przeprowadzania działań o charakterze obliczeniowym, ma bardzo długą historię. Od momentu, gdy pojawiła się pierwsza myśl w ludzkiej samoświadomości, u zarania pojawienia się koncepcji liczebności człowiek wykorzystywał różne metody, aby ten proces był łatwiejszy do przeprowadzenia. Na samym początku wystarczyło zapamiętanie w umyśle pewnych 
liczb, lecz w miarę upływu czasu operacje, jakie człowiek był w stanie wykonywać, zaczęły stanowić coraz większe wyzwanie. Ludzkość musiła przejść długą drogę od momentu, gdy zaczęto zaznaczać na skali ilość zdobytej zwierzyny do wytworzenia pierwszego urządzenia wspomagającego ich możliwości obliczeniowe. Pierwsze liczydła, abakusy (ze starogr. abax - tablica wypełniona piaskiem do rysowania figur geometrycznych i liczenia), pochodzą z Sumeru sprzed około III tysiąclecia p.n.e. Jego budowa opierała się o sześćdziesiątkowy system liczenia system dzisiaj obecny w jednostkach czasu, lecz początkowo używany też do obliczeń astronomicznych. System ten zaadaptowali arabscy uczeni, analizując pracę Ptolemeusza, a następnie matematycy. Wykorzystywano go do przeliczania ułamków - co należało do zainteresowań włoskiego matematyka Fibonacciego, czyli Leonarda z Pizy.

Obok cywilizacji Sumeru także Babilończycy używali podobnych narzędzi do liczenia. Zaadaptowanie tego samego systemu spowodowało jednak, że bardziej skomplikowane obliczenia okazywały się niezwykle trudne, wręcz niemożliwe. W czasach późniejszych również Egipcjanie, Grecy, Persowie korzystali z podobnych osiągnięć technicznych. W opracowaniach ${ }^{1}$ związanych z odkryciami archeologicznymi uznaje się, że najstarszym urządzeniem do liczenia, jakie odnaleziono w Grecji - kolebce zachodniej filozofii - jest tablica z Salaminy, datowana na czwarte stulecie przed naszą erą. Abakus został także wynaleziony w Cesarstwie Chińskim, za panowania dynastii Han, pod koniec II wieku p.n.e.

Jedynym urządzeniem (pozostającym nadal w większej części zagadką) wspomagającym człowieka w jego umiejętności liczenia i jednocześnie zdejmującym z niego część obciążenia związanego z zapamiętywaniem liczb, wyników działań składowych, wyznaczaniem części odległości i proporcji jest mechanizm z Andikíthiry z II wieku p.n.e. Jest to konstrukcja, która pozostawia w cieniu wszelkie formy liczydeł znanych nam przez wieki. Jej budowa i wymagana wiedza do opracowania urządzenia o tak wielu zastosowaniach skupionych $w$ jednym przedmiocie zmienia całkowicie spojrzenie na inwencję w sprawach możliwości komputacyjnych maszyn w czasach starożytnych. Mechanizm nazywany jest czasem pierwszym komputerem analogowym.

Pierwszy przypadek próby zbudowania tego urządzenia datuje się na lata 30 . ubiegłego stulecia. Podjął ją I. Theofanidis². Od tamtej pory sukcesywne próby

${ }^{1}$ S.K. Stephenson, Ancient Scientific Calculators, http://sks23cu.net/TSA/CB10/sksAncientSciCalc.pdf.

${ }^{2}$ I. Theofanidis, Sur l'instrument en cuivre dont des fragments se trouvent au Musée Archéolo-

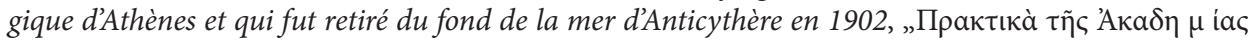

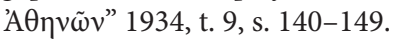


odtworzenia urządzenia miały miejsce dzięki wykorzystaniu urządzeń do tomografii komputerowej i przeglądów RTG. Dzięki temu wiele dekad później ingerencja w znalezione fragmenty na dnie Morza Egejskiego w 1900 r. mogła być minimalna, pozostawiając części urządzenia nietknięte. Kilka ośrodków zdecydowało się podjąć zadania odtworzenia urządzenia, próbując jednocześnie dokonać wstecznej inżynierii i odgadnąć prawdziwe jego zastosowanie. Spekuluje się, że urządzenie to miało przewidywać zaćmienia Księżyca i Słońca oraz śledzić pozycje planet w oparciu o arytmetyczną progresję babilońskiego systemu sześćdziesiętnego. Urządzenie śledziło 4 lata (co było klasycznym datowaniem dla Greków, jako że odliczało czas między olimpiadami), które były oznaczone datowaniem sotisowym. Jest to podział roku na 365 dni pochodzący ze starożytnego Egiptu. Mechanizm zawiera w sobie też podział na wiele innych cykli, których właściwe ustawienie na tarczy względem siebie pozostaje nadal nieustalone.

Urządzenie z Andikíthiry wyprzedza swoją złożonością wiele późniejszych konstrukcji, o których wspomina Cyceron w De Re Publica ${ }^{3}$. Następne urządzenia mogące dorównać tej złożoności pojawiają się dopiero w wiekach średnich. Jest to dowód na bardzo długą historię myśli komputacyjnej, która może pokazać, że samo zagadnienie obliczania zostało rozwinięte o wiele wcześniej, niż jak można byłoby zakładać.

Pierwszą osobą, która zaczęła tworzyć strukturalne diagramy hierarchii bytowej, lecz w ujęciu logicznym, jest Porfiriusz, którego życie przypada na III wiek n.e. Ujął on kategorie Arystotelesa w diagram w kształcie drzewa (stąd określenie Arbor Porphyriana - „drzewo Porfiriusza”). Jest to podstawa współczesnej taksonomii. Przełomowe jest tutaj wykorzystanie graficznego zapisu, by ukazać relacje w danej hierarchii między konkretnymi elementami.

Jest to metoda wykorzystywana do dziś w wielu dziedzinach. Sformułowanie takiego diagramu pozwala na łatwiejszą analizę zjawiska czy mechanizmu, który jest rozpatrywany. Dokonywanie takich czynności jak redukcja elementów czy dodanie nowych może być o wiele łatwiejsza, mając rozrysowaną mapę zależności (co w dzisiejszych czasach ukazuje choćby plug-in GraphViz w programie Protégé).

${ }^{3}$ M.T. Cicero, F. Barham, The Political Works of Marcus Tullius Cicero: Comprising His Treatise on the Republic, and His Treatise on the Laws, Edmund Spettigue, 1841. 
Ryc. 1. Drzewo Porfiriusza

IN PORPHYRIUN OIALOGOS 1.

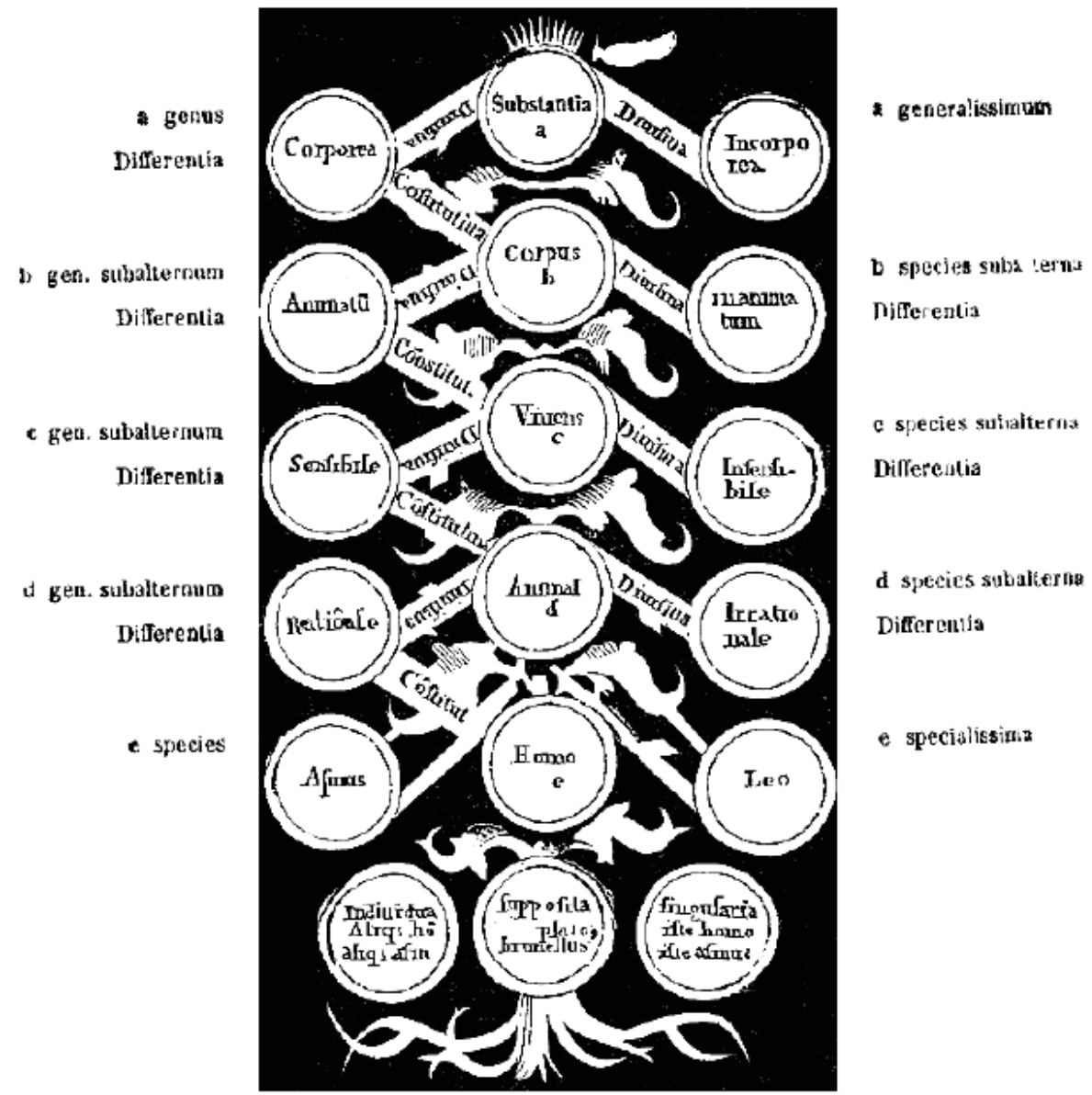

Źródło: Prawdopodobnie Boecjusz (przełom V-VI wieku).

Ważną postacią dla zagadnienia reprezentacji wiedzy po Porfiriuszu, który także bazował na jego dokonaniach i może być uznany za pierwszego człowieka, który zapisał się na kartach historii jako pomysłodawca zdalnego inteligentnego rozumowania, jest Ramon Llull - chrześcijański filozof, naukowiec pochodzący z Majorki, żyjący w XIII wieku n.e. Jego życiowe dzieło - Ars - było początkowo metodą popularyzacji chrześcijaństwa spełniającym wymogi pracy misjonarskiej, jak i pracy apologetycznej. Celem katalońskiego filozofa było stworzenie 
uniwersalnych podstaw teoretycznych dla rozważań trzech wielkich religii (chrześcijaństwo, judaizm i muzułmanizm). Narzędziami jego pracy była logika i metafizyka. Powodem stworzenia Ars była niezgodność interpretacji Biblii, która prowadziła do wielu sporów i konfliktów. Stąd też pochodziła chęć stworzenia jednolitego, uniwersalnie przejrzystego systemu reprezentującego podstawowe relacje obecne w świecie. Przykładem może tu być choćby wiara w jednego Boga, sprawiedliwość, istnienie świata. Jako opis świata Llull zaadaptował osiągnięcia Greków w tym zakresie, a jako podłoże teoretyczne - wykładnię Arystotelesa w dziedzinie logiki i metafizyki. Kataloński naukowiec przypisuje swoje odkrycie jednemu konkretnemu momentowi, który mógł stanowić zwieńczenie długiego okresu kontemplacyjnego, oraz działaniu intuicji wraz z boską interwencją. Całość tego doświadczenia spisał w Llibre de contemplació en Déu z 1274 r. Po pewnym czasie, jako że był człowiekiem zainteresowanym wieloma dziedzinami nauki (o czym świadczy duży dorobek dzieł, tak apokryficznych, jak i historycznych czy dokumentalnych), pomysł stworzenia uniwersalnego sposobu krzewienia wiary urósł do rozmiarów życiowego dzieła mogącego rywalizować z syntezą kamienia filozoficznego w alchemii. Ars zmieniła się w Ars Magna - praca, mająca na celu jednolite połączenie podstawowych zasad i relacji wszystkich dziedzin nauki konstytuujących wiedzę, w jedną, uniwersalnie zrozumiałą metodę badania, analizowania i kategoryzowania wszystkiego w obrębie istnienia. Próba osiągnięcia tego została wyłożona w Arbor Scientiae spisana na przełomie 1295 i 1296 r. w Rzymie . Jak wskazuje tytuł, jest to przedstawienie schematu drzewa (podobnego do dzieła Porfiriusza), na którym zostały opisane wszystkie podstawowe pojęcia, relacje i zasady danej dziedziny wiedzy, które konstytuują pewien wycinek rzeczywistości.

Układ czternastu drzew jest także hierarchiczny. Pierwsze z drzew przedstawia hierarchię cnót, które spływają na świat materii w określonej kolejności, następnie przedstawione zostaje drzewo elementów pokazujące relacje między żywiołami kształtującymi materię, a po nim drzewo wegetacji określające takie funkcje biologiczne, jak rozmnażanie i instynkt przetrwania. Dwa drzewa, na które warto zwrócić uwagę z punktu widzenia historii reprezentacji wiedzy oraz komputacji, to drzewo człowieka oraz drzewo wyobrażeń - pierwsze odnosi się do zdefiniowania wyższych funkcji kognitywnych człowieka, drugie natomiast opisuje potencjał dotyczący tworzenia reprezentacji obiektów z danych zmysłowych.

\footnotetext{
${ }^{4}$ R. Llull, Arbor Scientiae, Ex Officina Ioannis Pillehotte.
} 
Ryc. 2. Drzewo wiedzy

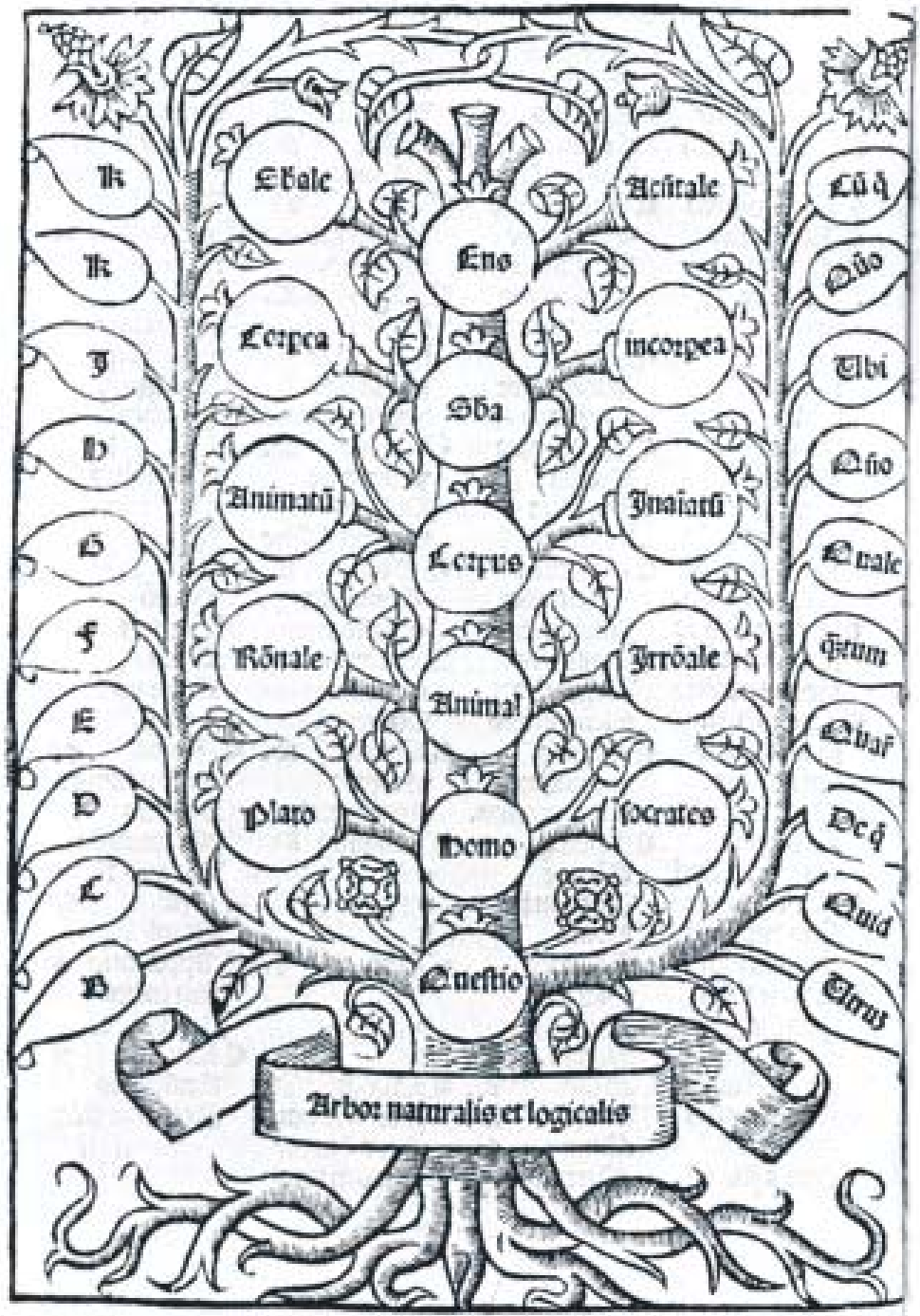

Źródło: John F. Sowa, http://www.jfsowa.com/krbook/.

Tego typu drzew w księdze Llulla znajduje się czternaście. Oprócz nich znaleźć też można dwa innego typu: drzewo przykładowe oraz drzewo pytań. Ich główną rolą było nauczenie poruszania się w obrębie pozostałych czternastu (drzewo przykładowe) oraz coś, co można nazwać pierwszą próbą stworzenia urządzenia wspomagającego ludzki intelekt (ostatnie z nich - drzewo pytań). Szesnaste 
drzewo składało się z głównego członu stanowiącego drzewo Porfiriusza w połączeniu z dwiema dodatkowymi gałęziami, na których znajdowały się ogólne rodzaje możliwych do zadania pytań (po prawej stronie) i zespół glyfów (strona lewa) odpowiadających systemowi obracających się dysków, które generowały odpowiedzi na typy pytań. Oczywiście zakres pytań dotyczył czternastu drzew odpowiadających różnym dziedzinom wiedzy. Jest to pierwszy udokumentowany przypadek stworzenia urządzenia, które miało wspomóc inteligentne rozumowanie. Ważną cechą całości Ars Magna było wykorzystanie podejścia interdyscyplinarnego jako narzędzia mającego zuniwersalizować funkcjonowanie urządzenia Llulla. Co więcej, podstawą teoretyczną było określenie wprost wykorzystania reprezentacji istniejących obiektów do wykonywania na nich operacji logicznych, co później zostanie określone jako aspekt surogacji reprezentacji wiedzy. Ukazanie drzewa Porfiriusza oraz drzewa wiedzy Ramona Llulla pozwala prześledzić rozwój

Ryc. 3. Pierwsze koło mechanizmu Llulla
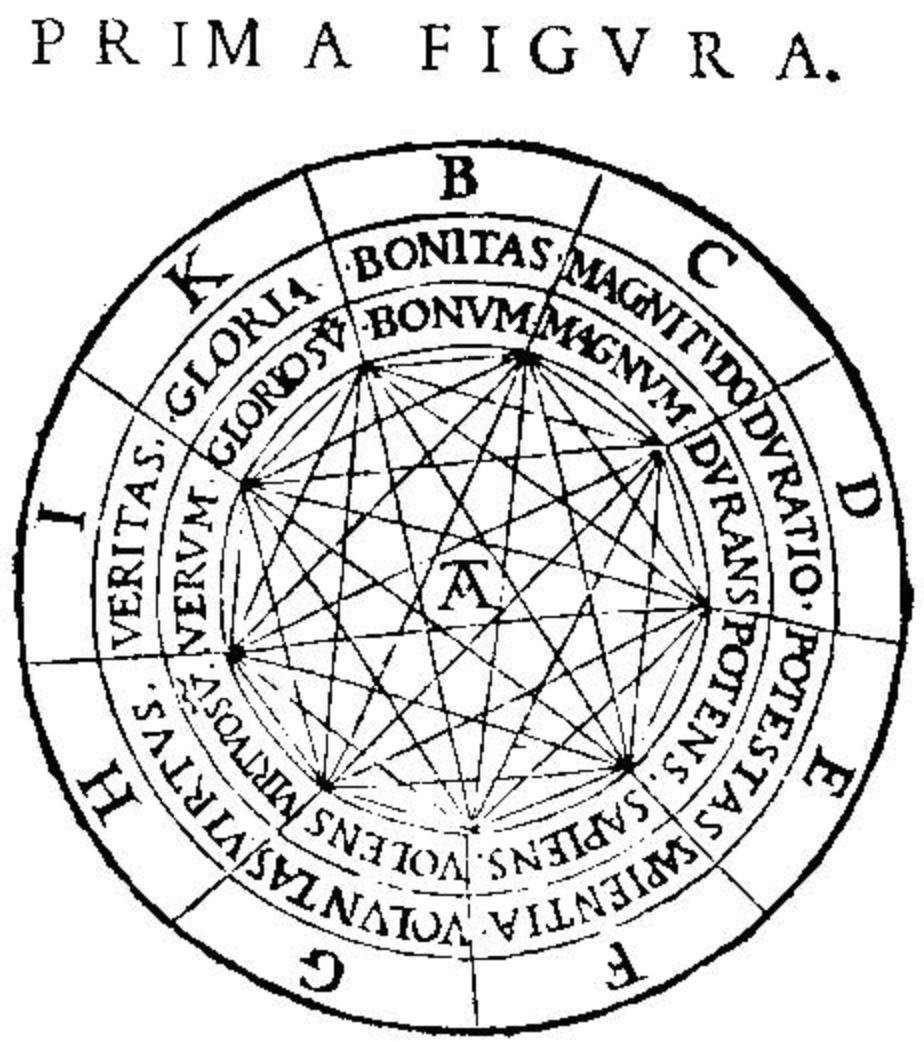

Źródło: http://history-computer.com/Dreamers/Llull.html. 
idei reprezentacji wiedzy i jej formalnego zapisu. W obu przypadkach schemat jest oparty na drzewie, przy czym rozwinięcie pierwotnego pomysłu (strona prawa) ukazuje też element stanowiący swoistą formę wytycznych interfejsu użytkowania urządzeń budowanych przez Llulla. Mowa tutaj o lewej gałęzi i wyrastających z niej liści, na których widnieją glyfy pomagające w nawigacji i kodowaniu w obrębie instrumentarium Ars Magna. Najprościej ujmując, nowatorstwo pomysłu Ramona Llulla ma swe źródło w próbie automatyzacji procesów logicznych. Pierwsze koło stanowi zespół liter mający określone znaczenie, w przypadku prezentowanym poniżej są to B-Bonitas, C-Magnitudo, D-Duratio, E-Potestas, F-Sapientia, G-Voluntas, H-Virtus, I-Veritas oraz K-Gloria.

Drugie koło określa kategorie i relacje dotyczące pierwszego z nich, wiążąc dwa mechanizmy w system pojęć i relacji. W ten sposób można tworzyć odpowiednie kombinacje i rozwiązania w formach tabel. Tego rodzaju kody mogły pomagać w automatyzacji dedukcji różnych problemów, na przykład w sferze teologii.

Ryc. 4. Drugie koło dopełniające urządzenie Llulla

\section{SECVNDA FIGVR A.}

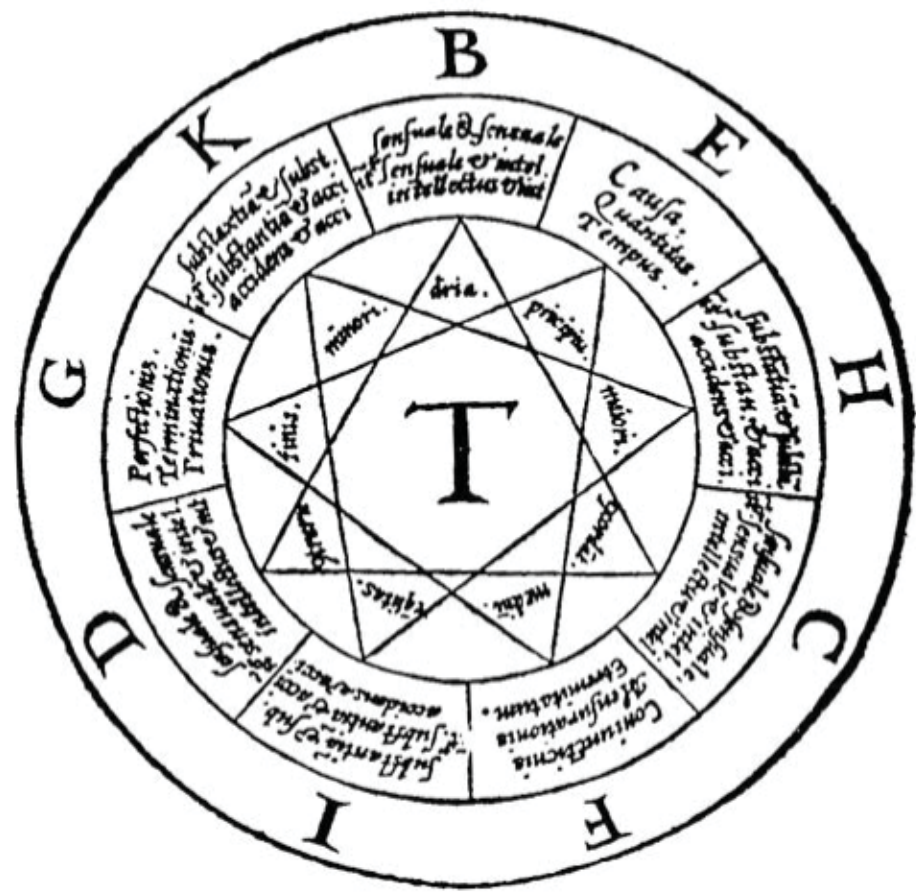

Źródło: http://history-computer.com/Dreamers/Llull.html. 
Dzieło filozofa z Majorki było silną inspiracją dla G.W. Leibniza, który to, wykorzystując swoje odkrycia w dziedzinie matematyki, dokonał modernizacji maszyny B. Pascala, Pascaline. Koła Leibniza były pierwszą maszyną, która potrafiła wykonać wszystkie cztery działania arytmetyczne: dodawanie, odejmowanie, mnożenie i dzielenie.

Prawdziwy przełom i świt tego, jak dziś patrzymy na operacjonalizację reprezentacji wiedzy, przypada na lata 1936-1943. Pierwsza data odnosi się do roku, w którym A. Turing sformułował ${ }^{5}$ pojęcie algorytmu i komputacji w oparciu o maszynę Turinga, tworząc pierwszy schemat nowoczesnego urządzenia, które było zalążkiem tego, co dziś znamy jako komputer.

Ważną kwestią w pracy A. Turinga był fakt, że odrzucał on pojęcie „inteligentna maszyna”. Był to dla niego paradoks, który tylko w dalekiej przyszłości mógłby być zwyciężony, i uznawał to tylko za ewentualność. Autor Computing Machinery and Intelligence ${ }^{6}$ zastanawiał się nad tym, czy inteligencja może w jakikolwiek sposób wyłonić się ze skończonej liczby rutynowych operacji o charakterze algorytmicznym:

„Skupmy się na jednym konkretnym komputerze C. Czy to prawda, że modyfikując ten komputer, tak, by posiadał odpowiednią pojemność, odpowiednią szybkość i uposażając go w odpowiedni program, C może zadowalająco odegrać rolę A w grze imitacji, gdzie rola B przypadnie człowiekowi?"?.

W kontekście wypowiedzi autora A oznaczało komputer ewaluowany testem Turinga, a B - inicjalnie komputer uposażony w zdolność przewidzenia każdego stanu automatu skończonego. Jego odpowiedź opierała się na założeniu, że ludzki mózg musi być zbudowany w taki sposób, który pozwala mu na swobodne osiąganie inteligentnego rozumowania, na dodatek jako automat skończony. Jest to iteracyjny model zachowania systemu dynamicznego opracowany na polu matematyki, który opiera się na wykorzystaniu diagramu definiującego dyskretne przejścia między danymi stanami. W przypadku Turinga jest to zgeneralizowany model jego sławnej maszyny (przypadek maszyny Turinga odróżniało to, że operował na nieskończonej pamięci).

${ }^{5}$ A. Turing, On computable numbers, with an application to the Entscheidungsproblem, „Proceedings of London Maths. Society" 1936, t. 2, s. 230-265.

6 A. Turing, Computing Machinery and Intelligence, „Mind” 1950, t. 50.

7 Tamże, s. 442. 
Ryc. 5. Formalny model automatu skończonego

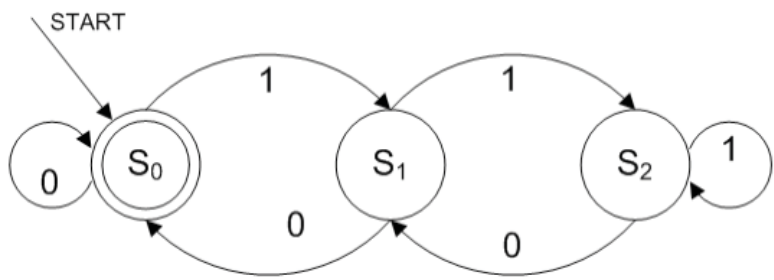

Źródło: P. Kadlec, Example of a DFA that accepts binary numbers that are multiplies of 3, http:// upload.wikimedia.org/wikipedia/commons/e/ed/DFA_example_multiplies_of_3.png.

Automat (w tym wypadku badający podzielność danej liczby przez 4) zaczyna pracę od stanu $\mathrm{S}_{0}$ i po otrzymaniu na wejściu (input) danej cyfry (bitu danych) może zmienić swój stan na Sj gdzie $j=\{0,1,2\}$. Automat zachowa się stabilnie, gdy po przetworzeniu danych stan wyniesie $S_{0}$. Informacja przekazana jest w kodowaniu binarnym dwójkowym (dla przykładu cyfry 4 kod binarny wynosi 0100). Jest to przydatne narzędzie do wykonywania różnego rodzaju eksperymentów myślowych. Dla Turinga sieć neuronowa funkcjonuje właśnie na takiej zasadzie. Wyciągnąć można $\mathrm{z}$ tego wnioski, że nie mamy nieskończonej pamięci operacyjnej, jesteśmy bytami skończonymi, a co za tym idzie - nasza neurologiczna konstytucja też jest ograniczona. Rzeczą najciekawszą jest to, że prowokuje to do podjęcia innego tropu badawczego: skoro jesteśmy ograniczeni zasobami i nie mamy dużej wolności w tworzeniu algorytmów i rutyny momentami wymagającej niewyobrażalnej mocy obliczeniowej, zatem musimy zastanowić się nad strukturą i wynikającymi z niej cechami oraz funkcjami. Wszelkie nowoczesne badania z zakresu nauk kognitywistycznych przyjmują taką ewentualność za wysoce prawdopodobną, a każda informacja o aktywnych obszarach mózgu i ich połączeniach w odniesieniu do funkcji poznawczych jest wielkim osiągnięciem i stawia nas o krok bliżej rozszyfrowania tajemnicy mózgu.

Największą sławę A. Turingowi przyniosła jego propozycja testu, który miał określić, czy dana maszyna jest zdolna do (szeroko rozumianego) inteligentnego rozumowania. Jako eksperyment myślowy można formułować go jako próbę przekonania obiektywnego sędziego przez człowieka i maszynę, który z nich jest człowiekiem. Test miałby przebiegać jako analiza tekstu pisanego, bez możliwości wglądu w jakiekolwiek inne informacje o danym uczestniku eksperymentu.

Mimo antycypacji nadejścia dnia, w którym maszyny będą zdolne do osiągnięcia pułapu inteligencji, Turing był świadom problemów związanych z oddzieleniem tej cechy od innych typowo ludzkich czynności. Po części może być to spowodowane brakiem rozpatrzenia kwestii statusu świadomości jako takiej i wstrzymania się od jakichkolwiek prób definicji, redukcji i analizy tego zjawiska. 
Problematykę na tym poziomie można odnieść do zawodności ludzkiego umysłu, który nie zawsze radzi sobie $\mathrm{z}$ taką samą sprawnością z choćby działaniami arytmetycznymi, nawet najprostszego typu. Można zadać tu pytanie: czy maszyna byłaby zdolna do takiej pomyłki? Tudzież gdyby została zaprogramowana do emulacji świadomości, czy byłaby w stanie zrobić to intencjonalnie (aby zachować pozór człowieczeństwa)? Wydawać się może, że taki przypadek nie spełnia wymogów inteligencji, gdyż wszelkie pomyłki człowieka nigdy nie były i nie będą intencjonalne, patrząc na to zagadnienie pod kątem świadomości.

Innym ważnym postulatem Turinga było zażegnanie sporu między projektowaniem a treningiem maszyn. W dzisiejszych czasach nadal nie ma konsensusu, które z podejść jest tym jedynym, najlepszym, jeśli chodzi o pracę sieci neuronowych. Londyńczyk uznawał, że zarówno programowanie, jak i podejście koneksjonistyczne może dać wymierne rezultaty i nie można odrzucać jednego z nich, faworyzując drugie.

Zastrzeżenia do teorii inteligencji według A. Turinga mogą pojawić się w kwestii emulacji funkcji umysłu za pomocą programowania, jak i redukcji tego procesu do działania automatu skończonego. Mimo że emulacja tego typu nie musiałaby odnosić się do adekwatności struktury wobec funkcji, to jednak próba naśladowania procesu inspiracji i kreatywnego działania, nawet w ramach sztuki, może być trudna do osiągnięcia. Mogłoby to sprowadzać sztukę do poziomu jedynie naśladownictwa, nie powalając tworzyć rzeczy spontanicznych, zupełnie różnych jakościowo od pozostałych reprezentacji najróżniejszych obiektów i cech, jakimi charakteryzuje się umysł.

Warto wspomnieć, że sukces komputerów i rozszerzenie pracy nad ich optymalizacją oraz rozbudową miał miejsce dopiero po II wojnie światowej, gdzie maszyny liczące wspomagały kryptografów próbujących rozwikłać szyfry zarówno strony alianckiej, jak i państw osi. Dopiero po zauważeniu sukcesów na tym polu suwaki logarytmiczne pomału zaczynały być wypierane przez kalkulatory, a miniaturyzacja urządzeń zdolnych do komputacji zaczynała nabierać tempa.

Biorąc pod uwagę obecne rozwiązania technologiczne, OWLViz jest plug-inem dającym możliwość graficznego przedstawienia relacji między obiektami zdefiniowanymi w zbiorze instancji programu Protege. Jest to podobny zabieg, który został również zastosowany u Porfiriusza i Ramona Llulla. W kwestii pozytywnej heurystyki metod reprezentacji wiedzy można uznać to za jedno z kluczowych narzędzi do prób eksperymentowania z różnego typu strukturami. Na podstawie takiego przedstawienia danej ontologii można stworzyć swoistą mapę wiedzy, dzięki czemu łatwiej prześledzić operacje logiczne. Taka struktura jest przejrzystym sposobem stworzenia materiału, w obrębie którego będą pracować algorytmy wnioskujące. 
Ryc. 6. Zrzut ekranu programu Protege 4.2 pokazujący plug-in OWLViz, ukazujący ontologię struktur molekularnych w fizyce (plug-in jest częścią GraphViz)

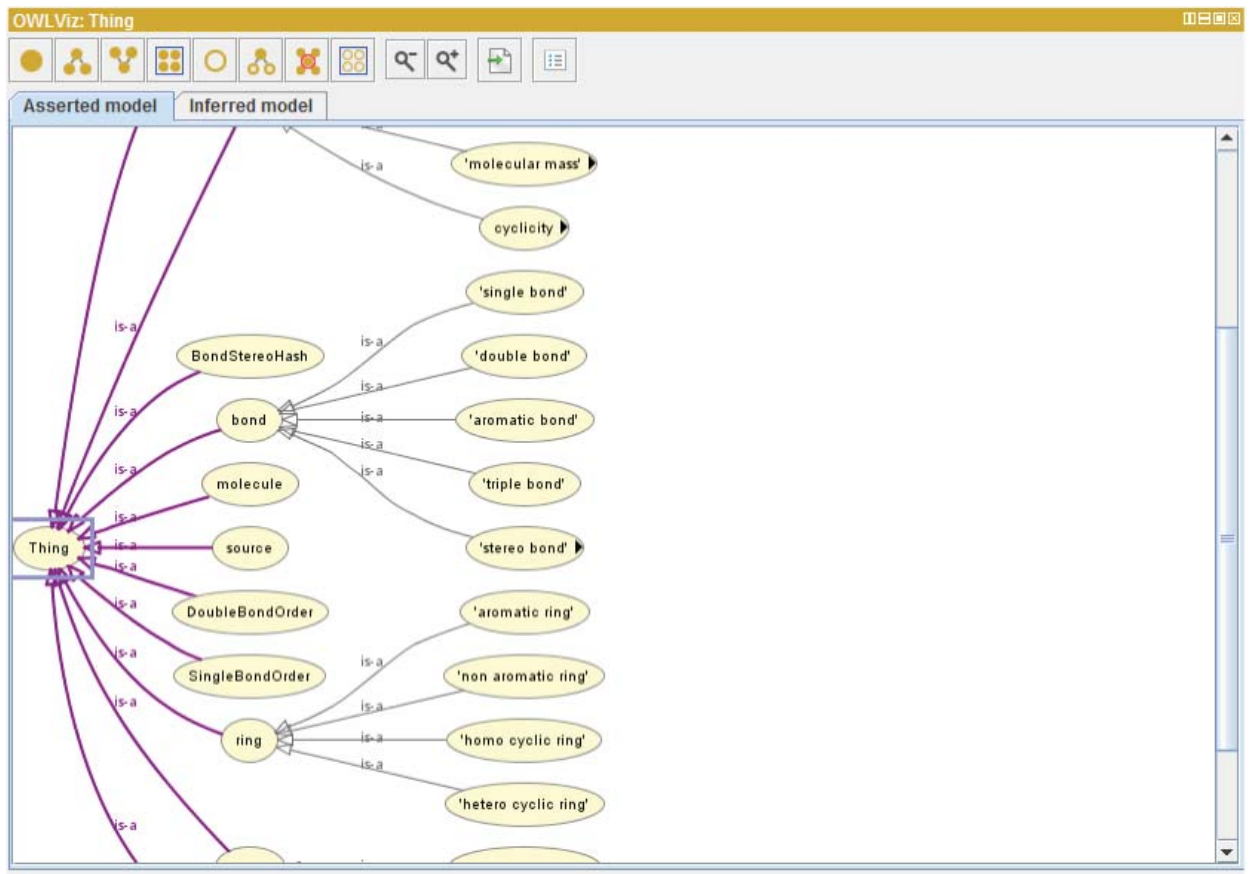

Źródło: Protege 4.2.

W perspektywie filozoficznej tego rodzaju intuicja znalazła też swój wydźwięk w pracy Ludwika Wittgensteina. Pojęcie podobieństwa rodzinowego (Familienähnlichkeit) oznacza, że rzeczy, które uznaje się za powiązane jedną wspólną cechą, $\mathrm{w}$ istocie mogą być powiązane zespołem częściowo nachodzących na siebie podobieństw ${ }^{8}$. Stało się to początkiem dla rozważań $\mathrm{w}$ ramach niestandardowych podejść do lingwistyki, semantyki oraz innych dyscyplin, takich jak kognitywistyka9.

Struktury tutaj zaprezentowane wykazują, że u podstaw wielu teorii próbujących rozwikłać zagadkę inteligencji, reprezentacji, operacji logicznych leżą

${ }^{8}$ L. Wittgenstein, Culture and Value, Londyn 1998, s. 14.

Oprócz Ludwika Wittgensteina wcześniej John Stuart Mill oraz Fryderyk Nietzsche korzystali z tego pojęcia, jednakże dopiero publikacje Wittgensteina zainteresowały szersze grono naukowców, co dało początek rozważaniom w ramach m.in. nauk kognitywnych poprzez np. teorię prototypów.

9 E. Rosch, Cognitive Representations of Semantic Categories, „Journal of Experimental Psychology: General" 1975, t. 104, nr 3, s. 192-233. 
wspólne elementy. Na dzień dzisiejszy nie istnieje kompletna definicja reprezentacji wiedzy, jednocześnie posiedliśmy wiele narzędzi, by to zjawisko badać. Jednak zrozumienie, z jakiego powodu pewna konfiguracja mentalnych konstruktów, która współgra z rozmaitymi możliwościami naszego umysłu, zdolna jest posiąść cechę inteligentnego rozumowania, stanowi jedno z najdonioślejszych aspektów badań w ramach m.in. inżynierii wiedzy, filozofii oraz nauk kognitywnych. Jednakże z uwagi na aspektowy charakter obecnych definicji, nie można umniejszać roli żadnej z wymienionych tu dziedzin, gdyż każda z nich wniosła ogromny wkład w rozwój badań nad zagadnieniem inteligentnego rozumowania.

\section{BIBLIOGRAFIA}

Badia L., Bonner A., Soler A., Who was Ramon Lull? - Tree of Science, URL = http://quisestlullus.narpan.net/eng/713_arbre_eng.html.

Cicero M.T., Barham F., The Political Works of Marcus Tullius Cicero: Comprising His Treatise on the Republic, and His Treatise on the Laws, Edmund Spettigue, 1841.

Davis R., Shrobe H., Szolovits P., What is a Knowledge Representation?, „AI Magazine" 1993, t. 14.

Llull R., Arbor Scientiae, Ex Officina Ioannis Pillehotte, 1635.

Rosch E., Cognitive Representations of Semantic Categories, „Journal of Experimental Psychology: General” 1975, t. 104, nr 3.

Theofanidis I., Sur l'instrument en cuivre dont des fragments se trouvent au Musée Archéologique d'Athènes et qui fut retiré du fond de la mer d'Anticythère en

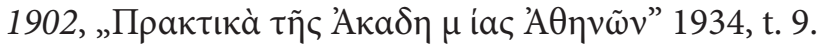

Turing A., Computing Machinery and Intelligence, „Mind” 1950, t. 50.

Turing A., On computable numbers, with an application to the Entscheidungsproblem, „Proceedings of London Maths. Society” 1936, t. 2.

Wittgenstein L., Culture and Value, London 1998.

Antikythera Mechanism Research Project, Project Overview, http://www.antikythera-mechanism.gr/project/overview. 